\title{
DEVELOPING DILEMMA DISCUSSION METHOD IN AKHLAQ LEARNING TO PROMOTE STUDENT'S MORAL REASONING
}

\author{
Ainul Yaqin \\ Universitas Islam Majapahit \\ Jalan Raya Jabon Km. 0,7 Mojokerto, Indonesia \\ Email: ainulyaqin@unim.ac.id
}

\begin{abstract}
:
Enhancing moral reasoning is the main goal of education in the perspective of cognitive-developmental theory. Strategies, approaches or learning methods are chosen based on the effectiveness in changing the level of moral reasoning of students from level of pre-conventional, to conventional and post-conventional. Dilemma Discussion Method has proven its effectiveness in increasing moral reasoning. Therefore, in order to be used in Akhlak learning (part of Pendidikan Agama Islam material) of the classroom, it is important to develop the steps of implementation (syntax) by using the principle of cognitive developmental theory. The results of this Research and Development (R \& D) Design indicate that the product in the form of learning syntax from Dilemma Discussion Method is declared as valid with a mean score of 4.38 (greater than the criteria). Thus the product of development research in the form of a dilemma discussion method in learning Akhlaq is worth for being implemented.
\end{abstract}

\begin{abstract}
Abstrak:
Peningkatan penalaran moral peserta didik merupakan tujuan utama pendidikan dalam perspektif teori cognitive-developmental. Strategi, pendekatan ataupun metode pembelajaran seharusnya dipilih berdasarkan keefektifannya dalam mengubah level penalaran moral peserta didik dari pre-conventional, menuju level conventional dan post-conventional. Metode diskusi dilema telah dibuktikan keefektifannya dalam meningkatkan penalaran moral. Oleh sebab itu, agar dapat digunakan dalam pembelajaran akhlak/moral (bagian dari mata pelajaran Pendidikan Agama Islam) di kelas, perlu diupayakan pengembangannya berupa langkah-langkah pelaksanaannya (sintak) metode tersebut dengan menggunakan prinsip-prinsip belajar cognitive developmental theory. Hasil penelitian pengembangan (Research \& Development) ini menunjukkan bahwa produk berupa sintak pembelajaran dari metode diskusi dilemma dinyatakan valid karena telah memenuhi persyaratan validitas produk yakni mendapatkan skor rerata 4,38. Dengan demikian produk penelitian pengembangan berupa metode diskusi dilema dalam pembelajaran akhlaq layak untuk diimplementasikan.
\end{abstract}

Keywords:

Dilemma Discussion, Akhlaq Learning, Syntax of Method, Moral Reasoning

How to Cite: Yaqin, A. (2021). Developing Dilemma Discussion Method in Akhlaq Learning to Promote Student's Moral Reasoning. Lentera Pendidikan : Jurnal Ilmu Tarbiyah dan Keguruan, 24(1), 42-55. https://doi.org/10.24252/lp.2021v24n1i5. 


\section{INTRODUCTION}

Moral or akhlaq building, according to Cognitive Developmental Theory, is intended to develop moral reasoning of students (Duska \& Whelan, 1975), which is the cognitive domain. The experts of moral education agree that the moral domain can be categorized into three types, they are cognitive, affective and behavior. Lickona (2005) said that the moral realm includes knowing, feeling and behavior. Likewise, Rest (1992) stated that it is common for reviews of morality to be seen from three parts: behavior, affection, and cognition. A higher level of moral reasoning is expected to be achieved by the students, because this level allows students to choose moral actions that are better, more in line with the expectations of society in general, at least not to deviate from the demands of applicable norms and laws. Students who are at the pre-conventional level, their behavior is only driven by the desire to get personal pleasure, whereas students who have stepped on conventional and post-conventional levels have been able to choose behavior beyond hedonic orientation. As Kohlberg stated that the level of moral reasoning consists of preconventional, conventional and post-conventional (Kohlberg \& Hersh, 1977). Meanwhile, according to Yaqin (2019), the level of moral reasoning in the context of moral science consists of awam, khawas and khawasul khawas.

Moral reasoning development, according to cognitive developmental theory, can be done by presenting learning that facilitates the process of perspective-taking, reciprocity, cognitive dis-equilibrium, progressive construction, and co-construction (Hoffman, 2000). Perspective-taking is the ability to understand the perspective of others. Piaget and Kohlberg argue that a mature moral judgment is obtained from the process of adopting different perspectives that others have (Timmerman, 2014). Reciprocity is the concept of justice; where one realizes that when a situation is handled in a way that appears fair, reasonable, and/ or beneficial to all participants, it becomes easier for people to accept and respect the decision. Cognitive disequilibrium is a condition that occurs when a person faces obstacles, contradictions, discrepancies, anomalies, uncertainties, and prominent contrasts (Mello, 2010). Progressive construction or constructivist construction is a process that shows a person's active construction about moral meaning and the development of a personal commitment to the principles of justice and concern for the welfare of others through a process of social interaction and moral discourse (Nucci, 2015). Students who has experience in cognitive processes will be able to increase their moral reasoning. These processes can change the pre-conventional level owned by students to conventional and even post-conventional levels.

The process of changing one's reasoning can be seen from how reasoning works or how to learn cognitive. According to Piaget (1977), cognitive learning process consists of three stages, namely assimilation, accommodation and equilibration. The first stage (assimilation) is the learning phase where new knowledge is entered into the mental structure of students, so that the student's knowledge memory increases. The second stage (accommodation) is the learning phase where the student's mentality is forced to adjust toward the new knowledge he/she receives and in this process students have experience a mental imbalance (disequlibrium) due to the presence of new knowledge that conflicts 
with the old knowledge that first exists in the students themselves. The third stage (equilibration) is the stage of mental balance that grows after mental conflict can be overcome (Pritchard, 2009). In the context of moral reasoning, a person moves from one level to another, because he/she has experienced a condition called disequlibrium, cognitive conflict resulting from the learning process such as an existance of explanation or problem solving, which changes one's cognitive scheme (Moreno, 2010). Cognitive conflict that is presented can encourage someone to realize the limitations of their views, so they are willing to accept a new perspective (Duska \& Whelan, 1975). However, cognitive conflict in a person must be ended, namely the equilibration process. When the equilibration process has taken place, the mental process in cognitive learning above can produce mental states of students who have been able to accept and believe that the knowledge that has been accommodated is true and he/she is committed to heading toward that knowledge. The mental state that is manifested in the form of peace and stability of the mind after finding the answer that is considered the most appropriate is called equilibrium.

The process of moral building also needs to present constructive principles in learning. The characteristics of constructivist moral learning according to DeVries \& Zan (1994) include: The atmosphere of a moral learning class is felt by the learners comfortably, as comfortable as teachers. There is no fear and unwillingness of students to ask or express their opinions. The teacher guarantees the students' need to be active, including the need to be interactive. Constructivist teachers promote peer interaction by organizing programs, so that interpersonal involvement occurs naturally. Constructivist teachers also encourage students to talk with each other, not just with the teacher. This cognitive and constructivist learning processes are demanded by cognitive-developmental theory in order that educators provide them in moral learning. Learning components that support cognitive and constructivist processes can be in the form of learning methods, media or teaching materials. The learning methods that are theoretically recommended are: Value Clarivication Technique, Moral Dilemma Discussion, Consideration and Problem based Learning (Yaqin, 2019b). In this study, the researcher focuses on the MDD method with a view to gaining a complete understanding that can provide adequate explanations for educators to implement it.

Moral Dilemma Discussion (MDD) has been introduced by Blatt-Kholberg and has been tested in various scientific fields by some assumption as follows (Lind, 2002): (1) Moral is more influenced by the ability of individuals to implement the moral values in the conflict situations. These situations require individuals to use their abilities in providing moral judgments about the problems they face, (2) The ability to act based on moral values (moral competencies) can be strengthened in everyday life since childhood, adolescence, adulthood and can be done in the family, school, higher education and the work place, and (3) The ability to act based on moral values can be improved by providing a learning environment where the students are confronted with moral problems and they can express the moral choices freely that they think best and get an appreciation of the 
opinions and arguments they present. The moral reasoning skills of students are proved to be increased when moral teaching is carried out using MDD (Latif, 2000). Delinquency of students also reduced and the quality of behaviour improved by implementing a teaching program based on MDD (Claypoole, Moody, \& Peace, 2000).

Moral maturity in the form of reasoning can guide students to choose the right attitude and action. Maturity of students' thinking about morals is a factor influencing moral decisions. The good and bad choices of student behavior depend on whether or not mature ways of thinking about morals. Therefore, Akhlaq learning needs to be designed to provide students with experience in facing the problems of implementing values, that is by providing self-experience in cognitive processes, from assimilation, accommodation, and equilibration, to increase moral maturity. Piaget's version of cognitive learning is chosen by the researcher to be the syntax or the steps of moral developmental learning based on Cognitive-Developmental Theory.

Based on the name of Moral Dilemma Discussion (MDD), it is required to present a trigger for discussion that contains a dilemma or problematic thing about morals. One of them is a moral story. Kohlberg used moral stories (story and probe question) to develop and measure one's moral reasoning (Duska \& Whelan, 1975). Moral stories are considered able to stimulate cognitive processes in the Moral Dilemmas Discussion during the learning process. In addition, it can be used for developing moral reasoning tests. Moral stories that are presented in moral learning, encourage students to express their opinions (perspective-taking) on the choice of actors behavior in the story with justification reasons (arguments). Every opinion that comes into the discussion is expected to provide an enriching perspective on students. In discussions with this story, students get information that in one particular event or problem, it turns out that various perspectives on behavior choices and their arguments can be given. Thus, students have the opportunity to be able to judge which of the appropriate behavioral choices to choose and hold on to behave.

Kohlberg and Blatt who used hypothetical dilemmas, moral stories that is not from the actual events, but it can occur in real life (Snarey \& Samuelson, 2014). Moral stories with hypothetical types are designed to present moral differences or moral conflicts that can be used as a stimulus for the students to discuss. However, according to Gilligan quoted by Balakrishnan (2009), real-life dilemmas have advantages over hypothetical dilemmas, because they are more practical and realistic in understanding students' moral views. Leming cited by Higgins, Power, \& Kohlberg (1992) also have the same view that a hypothetical moral story cannot represent a real problem of life, so they suggested to use real-life stories.

The use of a hypothetical dilemma-based moral story by the consideration that finding a real-life dilemma-based moral story that is appropriate with the theme of moral learning is very difficult and takes a long time, so for practical needs, it is used a hypothetical dilemma-based moral story. Researcher got one real event, that was the case of Fidelis who gave marijuana as a drug to his wife who was sick and he expected to cure his wife by using it. Fidelis was eventually sentenced to eight months in prison, although his aim was to save his wife's life. The dilemma is whether Fidelis' actions are wrong or 
right? Fidelis' actions can indeed be categorized as a violation of law in Indonesia and obedience to the rules that is an embodiment of values that is referred to as a conventional level reference. However, the reason for saving one's life is the implementation of human values that can also be justified because it is a noble value that is made a standard for postconventional level. This event can be used as a real-life dilemma as a trigger for discussion of Akhlaq learning.

Moral stories provided in the textbooks are used to ignite the discussions. Moral stories also need to be supplemented by a number of key questions to stimulate Moral Dilemmas Discussion. Nevertheless, the types of questions provided by Kohlberg got criticism from Leming. According to Leming quoted by Higgins, Power \& Kohlberg (1992), the questions that Kohlberg provides regarding moral stories tend to be prescriptive (what should be done), for example what you should do if you are in a situation faced by the characters in the story. Supposedly, according to Leming, the questions asked are descriptive (what would be done), because descriptive questions provide the real situation needed in moral decision making. Leming's criticism certainly needs to be considered in creating teaching material (the moral stories and the questions) in order to bring moral learning that is helpful for the development of students' moral reasoning.

\section{RESEARCH METHOD}

This research uses Research and Development (R\&D). Borg \& Gall (2003) stated that Research and Development (R\&D) aims at producing new products or procedures, and systematically testing them in the field of research in order to obtain the specified qualifications such as effectiveness, quality or other standards. The product designed in this research is the Dilemma Discussion Method used in Akhlaq learning (part of Pendidikan Agama Islam) based on a cognitive approach. The development of moral learning methods based on cognitive theory refers to Plomp model (1997) which takes five phases, they are (1) Investigation, (2) Design, (3) Construction, (4) Evaluation, and (5) Implementation. The research product in the form of Dilemma Discussion Learning Method, was validated by the expert judgment, it means that the product was reviewed by experts ( 4 people) and practitioners ( 3 people). The expert is a person who has a doctoral education qualification or level 9 competency of KKNI; Kerangka Kualifikasi Nasional Indonesia or Indonesia Qualification Framework (Sugiyono, 2016). Meanwhile, the selected practitioners are teachers who teach Aqidah-Akhlak at Madrasah Aliyah. The criteria used are the results of the development can be considered as a valid method, if the average score of at least 3; average> 3 (Khabibah, 2006). The researcher designed a prototype of the dilemma discussion method in Akhlaq learning by providing a learning syntax based on moral cognitive development theory. Researcher also compiled a validation form based on the latest learning theory. The prototype was given to the validator to get an assessment and suggestions for improvement according to the validation form provided. Furthermore, the researcher made improvements to the prototype according to the validator's suggestions and submitted it back to the validator 
to get re-validation until the prototype got the score above the criteria so that it was declared valid and could be called a development product.

\section{RESULTS AND DISCUSSION}

One of the elements that needs to be designed in planning Akhlaq learning is the learning method. The method of Dilemmas Discussion in the expert's view can broaden students' perspectives, because this method gives space for each student's ideas and thoughts of the students can be expressed, so there are many alternative views about morals that can enrich student understanding. Students can recognize each idea and the supporting arguments. Cognitive work methods can be well facilitated. Based on this point, the researcher chose the method of Dilemma Discussion as part of supporting the Akhlaq learning model based on cognitive development theory.

In the Dilemma Discussion, the topic of discussion was prepared as a syllabus of moral subjects supplemented with moral stories. Then the students were divided into some groups to discuss the topic. After the groups discussion were finished, it continued the class discussion, where each group member was asked to tell how they could solve the dilemma that is presented and the students should be able to explain the moral principles that underlie the solution. This discussion activity is designed in order that the students can increase the moral reasoning from lower to higher as Kohlberg's moral reasoning hierarchy. Students are predicted to have the development of their moral reasoning when they listen the arguments of group members who implement moral principles that represent higher moral levels. Certainly, the students who participate in groups with a high degree of equality and reciprocity will improve their level of moral reasoning more than the students who participate in such low discussions.

This discussion of the dilemma in Akhlaq learning requires a democratic condition, as it is required in constructivist learning. Each class member gets an equal position with other students and gets the same opportunity in the discussion. If inequality occurs, the students will not be motivated to explore solutions to the moral dilemmas, even the students are reluctant to express their opinions, even though they may have arguments about high moral principles and they are needed by the class. Consquently, at the beginning of each lesson, the teacher is recommended to remind all students to respect each other and appreciate each idea or thought of other students. This democratic atmosphere is expected to be able to encourage positive interactions among students, so that they are able to discuss well.

Based on the cognitive theory construct above, dilemmas discussion method in akhlaq learning is designed based on the followings syntax:

Table 1. Dilemmas Discussion Method in Akhlaq Learning is Designed Syntax

Phase Build awareness to obey the class norms

I 1. Beginning the lesson by explaining the learning objectives and the instructional process that will be carried out to achieve them.

2. Asking the class to uphold the rules and create a good classroom atmosphere in interaction among students. Emphasizing the importance 
of everyone's opinion, there is no right answer and the other is wrong, and must listen actively.

Phase Creating disequlibrium by presenting a moral story with a dilemma

II 1. The teacher introduces the moral dilemma by reading the dilemma moral story slowly and clearly.

2. Asking students to read individually or trying other approaches that are more creative.

3. Asking students the parts that have a dilemma

4. Asking students to draw conclusions/summaries of stories and issues/ problems

5. The teacher ensures that students truly understand the dilemma by asking students to review roles in the story.

6. Asking students about which roles/figures have problems and ask them to explain the problem.

7. Asking students about important points from the story presented.

Phase Developing ideas about various moral behavioral choices and the moral III reasons that support them

1. Asking students to think about the dilemmas and behavioral choices that a character can choose to solve a problem.

2. Asking each student to choose one of a set of actions.

3. Asking students to express their choices in class by raising their hands or by voicing their choices.

Phase Presenting the process of assimilating moral behavior by discussing it in a IV small group

1. Make a group that consists of 5 students

2. Give assignments to each group to:

a. Each group identifies all ideas related to the choice of actions that the character can choose.

b. Each group agrees to the choice of action that is considered the best.

c. Each group agreed on the reasons for the choice.

d. Ranking choices (the best reason first, second best reason, third best reason and so on).

3. Providing a time limit, so that the group can complete the task on time.

4. Making a visit to each group to listen and provide ways of completing the assignment if needed.

Phase Creating an accommodation process by agreeing on a sequence of moral V behaviors from behaviors that have the highest moral weight to the lowest

1. Re-uniting all students in a class discussion

2. The teacher acts as the leader of the discussion and provides guidance on class discussion

3. Asking each group to present the results of their group discussion 
Phase Reflecting on learning outcomes by reinforcement that produces equilibrium

VI 1. Asking students to present their personal opinions about the dilemmas contained in moral stories.

2. Asking each student to choose the best moral action option for the character in the story. The teacher needs to make the students able to change their thinking. If students have written their choices on paper, after discussion the teacher asks students to rewrite their choices on the flip side of the paper.

3. Asking students to choose the most appropriate reason for the chosen action. The teacher gives a guarantee that students can change their reasons after the discussion even though they are different from the previous reasons. The teacher asks students to re-write their reasons even if they do not change.

4. Asking volunteers from students to express the opinions whether the discussion carried out affects his/her thinking about moral issues, or asks students to write it.

5. Providing follow-up tasks, including:

a. Students are asked to discuss the dilemma with family.

b. Students are asked to watch certain films, TV programs or read books related to the theme of the dilemma.

c. Students interview other people (family, community leaders, neighbors) about the moral dilemmas or issues that have been discussed.

d. Asking students to find examples of dilemmas or moral issues on other occasions.

e. Asking students to write the conclusion of the discussion about dilemma.

When the process of assimilation in Akhlaq learning is conducted, the students take or understand existing events by matching the perceived characteristics of these events with the schemes that already exist in themselves. Previously the students have been conditioned to read or study a story or event with various choices of moral behavior from the actors. The students have also discussed various views or ideas proposed by other students. The students also have learned teaching materials that contain moral values in addressing the event. As a result, the process of matching external stimuli arises with the mental structure (schemata) that the students have had before, not only getting the objective reality offered, but also reshaping and interpreting the event, so that it forms a new schemata. For example, when the students are confronted with a trendy and glamorous women's dress behavior, with the schemata they possess, students respond by identifying such behavior as westernized or redundant and show off behavior. This happened because he/she already has the scheme in him/herself since before he was given the description. This is what is meant by assimilation or matching of stimuli from outside with the position that has been previously had. 
After moral learning presents the process of assimilation, it is continued with accommodation. During the accommodation process, the students revise or add schemes, so the students readjust stimuli from their environment that cannot be done easily. The students identify the process of adjusting the existing schemes to allow understanding of events or things that are unintelligible or unacceptable. For example, in responding to women who dressed trendy and glamorous, the students revised their view that this was a show off behavior by replacing it as the behavior of a great Muslim dress. However, the revision has not fully become the scheme or its establishment. This process can occur with stimuli in the form of opinions or thoughts presented to students by other students during a Dilemma Discussion that the reason for women's clothing is to show how to dress according to Islam that can adapt to the modern era, not out of date.

Before the process of assimilation and accommodation, the students' mental states are in a state of equilibrium (balance). Nevertheless, by the process of assimilation and accommodation, the students experience disequlibrium (mental imbalance). This happens because the students occurs the moral conflict. The conflict was intentionally created by presenting a different view of what was believed to be true by students, so that there was an upheaval of thinking for students. Therefore, it needs an equlibration process. Equilibration is a cognitive process to rebalance the mental atmosphere due to conflict or moral dilemmas. In helping the presence of equlibration, moral teachers are asked to design feedback activities in the form of opinions from students or teachers themselves who are able to help students get clarity of moral thinking and can make moral choices with strong conviction. Reliable arguments or propositions can help students find equilibrium. The dilemma discussion method developed based on this cognitive theory. Validity was assessed by using three indicators; (a) the discussion method has a learning syntax that contains the process of assimilation, accommodation and equlibration as cognitive learning theory, (b) the discussion method learning syntax is in accordance with the constructivist approach in cognitive learning theory, and (c) the discussion method learning syntax supports the enhancement of moral reasoning students; pre-conventional, conventional, post-conventional, as the following table.

Table 2. Indicators of Learning Syntax in the Dilemma Discussion Method

\begin{tabular}{ll}
\hline \multicolumn{1}{c}{ Rated aspect } & \multicolumn{1}{c}{ Rating Indicator } \\
\hline & $\begin{array}{l}\text { (RI1) Learning syntax contains the processes of assimilation, } \\
\text { accommodation and equality as cognitive learning theory. }\end{array}$ \\
\cline { 2 - 3 } Learning Syntax & $\begin{array}{l}\text { (RI2) Learning syntax is in accordance with the constructivist } \\
\text { approach in cognitive learning theory. }\end{array}$ \\
\cline { 2 - 2 } & $\begin{array}{l}\text { (RI3) Learning syntax can support the increasing student } \\
\text { moral reasoning; pre-conventional, conventional, post- } \\
\text { conventional (moral learning objectives). }\end{array}$ \\
\hline
\end{tabular}

The dilemma discussion model designed by the researcher was given validation by the experts and practitioners with the following results: the validity value of the cogitive 
process for Dilemma Discussion Method is 4.71 (valid), the constructivist approach's validity value is 4.48 (valid), the validity value of the support element towards increasing reasoning moral is 4.57 (valid). The results of validity test for Dilemma Discussion Method can be described as the following table:

Table 3. Data of Syntax Validity for Dilemma Discussion Method

\begin{tabular}{cccc}
\hline RI1 & RI2 & RI3 & Mean \\
\hline 4.71 & 3.86 & 4.57 & 4.38 \\
\hline
\end{tabular}

Based on the validity test criteria that have been determined, it is known that the results of the validator's assessment towards the indications of this method shows that the syntax of Dilemma Discussion Method is valid because the average score is 4.38 ad it is above the standard of validity. Thus, Dilemma Discussion Method can be accepted or meet the feasibility as the Akhlaq learning method based on cognitive developmental theory, so that it can be implemented.

One of the learning methods recommended by cognitive theory in developing students' moral reasoning is Dilemma Discussion. The use of this method has been proven to be effective way in increasing students' moral reasoning (Yaqin, 2019c). The development of moral reasoning can occur because there is a cognitive process that produces disequilibirum, so that it changes the schemata of students. This is in line with the theory proposed by Piaget and Kohlberg and also it is in line with the research of Matthew A. Holsapple and Samsul Susilawati. According to Piaget and Kohlberg, cognitive stimulation is the main factor in creating one's moral reasoning. Cognitive stimulation was done by providing situations that make students' mental states in equilibrium (Duska \& Whelan, 1975). The situation can be in the form of solving moral problems. This activity helps the development of cognitive structures in which students, for the first time, have a limited perspective then they are gained to have a new perspective in addressing moral problems. Holsapple's research (2014) results also have the same conclusion, that the development of moral reasoning is determined by a factor called equilibirum. The more frequent learning activities, it can facilitate the occurrence of equilibrium in students themselves, the higher the probability of the moral reasoning will increase. Holsapple stated that the students who were reported more frequent classroom encountered with disequilibrium exhibit higher levels of moral judgment. It is in line with Holsapple, Susilawati's research (2014) that took the students' university as the research subject. The research showed the same results, namely the level of moral consideration of students who were taught using the Dilemma Discussion Method based on cognitive approaches were significantly different, when it was compared with the students who were taught with the question-answer lecture method that is developed based on an investment approach. In this case, the moral consideration level of students taught by using the Dilemma Discussion Method is better than the students taught by the lecture-answer method.

The Dilemma Discussion Method has effectiveness in increasing moral reasoning because this method can provide cognitive processes, from accommodation, assimilation and equlibration that can change students' schemata. Good discussions can provide disequilibrating experiences for the students and it can encourage the development of 
moral reasoning in a higher level (Narvaez, 2006). Therefore, Snarey and Samuelson (2014) concluded that the Dilemma Discussion Method is a useful method for moral development. The discussion method that has been prepared well and equipped with teaching materials, then it has dilemma moral stories, is interesting, challenging and contains elements of curiosity for students. In this condition, the students usually experience disequlibrium conditions and feel uncomfortable, because the problems in their mind have not received satisfactory answers. This disequilibrium condition is preceded by other cognitive processes, namely accommodation and assimilation. When students have got answers to the problems they think about, the disequilibrium condition changes to equilibrium which eliminates discomfort in the minds of students. This condition can be called as stable and normal conditions. Cognitive processes in learning process have been able to change students' schemata. Schematic changes can occur when students have accommodated new knowledge structures into the schemata they have, so that the schemata structure that the students have changed from the previous conditions to the new schematic conditions. The description of this schematic change can be known from one example of the Trendy Hijab case, in which at first time, one of the students viewed it as useless thing which is contradicted with Islamic value, but after listening to various explanations and arguments from other students in the discussion, the students open minded to one of the noble goals of the creative process in trendy hijab production activities, which enables the emergence of goodness and useful thing from it. Changes in the schemata structure of the students also occur, and it is the results of learning practices using Dilemma Discussion.

Kohlberg and Fenton have also succeeded in proving the effectiveness of Dilemma Discussions Method in improving students' moral reasoning. Unfortunately, after this research has been conducted, no teacher is willing to adopt it. Kohlberg was frustrated, then he said: the operation was a research success but the research patient died (Power, Higgins, Kohlberg, \& Reimer, 1989). There are some reasons why the teachers did not implement it, they are: (a) the objective of Moral Dilemma Discussion (MDD) learning is not required by the curriculum, and (b) the implementation of MDD causes students to be lack of discipline, thus the teachers did not have willingness to implement MDD.

The implementation of MDD have its own challenges. One of them was found in the Yaqin study. The MDD experiment by teachers in the six sessions relatively run well and full of enthusiasm from the students. However, at the fifth meeting, the students were lack of motivation because of thinking too long time during the learning process (Yaqin, 2020). To be able to understand and analyze and provide a moral perspective, students are required to be philosophers who need great energy. As a result, the students feel tired and boredom.Related to the problem of boredom, the teacher can minimize it by choosing several alternative discussions to increase the effectiveness of Akhlaq learning. Firstly, designing each group consists of students who have a higher level of reasoning, avoiding the alignment of the reasoning level of all members and avoiding deadlocks in discussion. Second, presenting the senior in the classroom as a companion or leader in the discussion 
of a moral dilemma that can provide a moral perspective at a higher level than the students already have. Third, ask the students to discuss out of the classroom with the community or group that the teacher considers appropriate and able to help students improve their moral reasoning skills.

Besides it can overcome the problem of boredom, Dilemma Discussions Method conducted with senior or people who have moral maturity (people who have a higher level of moral reasoning), this way is also guaranteed to be more effective when the junior students learn with senior students. Kolberg stated that a person's moral reasoning will increase more quickly when discussions of moral dilemmas are carried out with people who have a higher level of moral reasoning. Kohlberg's statement has been proven in the work of Walker and other experts as quoted by Snarey and Samuelson (2014). Walker stated that moral reasoning of high school students increased significantly when the class conducted discussions with other students who have two levels higher of moral reasoning. Gibbs \& Broughtoun who examined the students' moral reasoning and got the results that the effectiveness of the discussion is better when the students discuss with people who have one third higher moral reasoning.

Related to the problems that occur when learning takes place with a dilemma discussion approach, then one way that can be done is to replace the hypothetical moral story with a real moral story. Based on the stories which are taken from everyday life experiences, students can be encouraged to frame problems from their own moral dimensions. They will also learn about moral conflicts that commonly occur in schools that they have never thought of before. By presenting a moral story from everyday problems, it is possible to encourage students to act on what they decide during group discussions (Power, Higgins, Kohlberg, \& Reimer, 1989). It includes the disciplinary problems discussed, it is likely to be used as a guide for students to be disciplined as agreed in the discussion.

\section{CONCLUSION}

The development of moral reasoning on the students is the main goal of moral education in the perspective of cognitive-developmental theory. The use of appropriate learning methods can encourage the development of moral reasoning of students from low levels to higher levels. Therefore, it is necessary to develop a dilemma discussion method in Akhlaq learning that is in line with this theory. The development product in the form of learning syntax from the dilemma discussion method in Akhlaq learning has been validated by the experts and the practitioners and got a mean score of 4.38 (greater than the criteria). Based on the results of this research, the Dilemma Discussion Method is considered as valid method and it is suitable to use in Akhlaq learning, because it covers at least three required criteria or indicators. The Dilemma Discussion Method is more effective if it is done with partners who have a higher level of moral reasoning. Therefore, Dilemma Discussion Method can be modified by presenting partners from senior students, parents or other adults, not just the students in the same class. Moral stories used in the discussion of moral dilemmas should be more varied, not only using hypotetichal stories, 
but also it can present real-life stories experienced by students themselves or real events that occur in the school or home environment.

\section{REFERENCES}

Balakrishnan, V. (2009). Teaching Moral Education In Secondary Schools Using Reallife Dilemmas. Victoria University Of Wellington.

Claypoole, S. D., Moody, E. E., \& Peace, S. D. (2000). Moral dilemma discussions: An effective group intervention for juvenile offenders. Journal for Specialists in Group Work, 25(4). https://doi.org/10.1080/01933920008411682.

DeVries, R., \& Zan, B. S. (1994). Moral Classrooms, Moral Children: Creating a Constructivist Atmosphere an Early Education. New York: Teachers College Press-Columbia University.

Duska, R., \& Whelan, M. (1975). Moral Development; A Guide to Piaget and Kohlberg. New York: Paulist Press.

Gall, M. D., Gall, J. P., \& Borg, W. R. (2003). Educational Research: An Introduction. Boston: Allyn and Bacon.

Higgins, A., Power, C., \& Kohlberg, L. (1992). Pertautan Suasana Moral terhadap Pertimbangan Tanggung Jawab. In W. M. Kurtines \& J. L. Gerwitz (Eds.), Moralitas, Perilaku Moral, Dan Perkembangan Moral. Jakarta: UI Press.

Hoffman, M. L. (2000). Empathy and Moral Development; Implication for Caring and Justice. New York: Cambridge University Press.

Holsapple, M. A. (2014). An Examination of Moral Judgment in College: Integrating Developmental and College Impact Frameworks. Michigan University.

Khabibah, S. (2006). Pengembangan Model Pembelajaran Matematika dengan Soal Terbuka untuk Meningkatkan Kreativitas Siswa Sekolah Dasar. Universitas Negeri Surabaya.

Kohlberg, L., \& Hersh, R. H. (1977). Moral Development : A Review of the Theory. Theory Into Practice, 16(2). https://www.jstor.org/stable/1475172.

Latif, D. A. (2000). The relationship between pharmacy students' locus of control, machiavellianism, and moral reasoning. American Journal of Pharmaceutical Education, 64(1).

Lickona, T. (2005). The Return of Character Education. Iowa: McGraw-Hill/Dushkin.

Lind, G. (2002). Moral Dilemma Discussion Revisited; The Konstanz Method. 28th Annual Conference: Conflict, Contradiction, and Contrarian Elements in Moral Development and Education.

Mello, D. (2010). Modeling Cognitive-Affective Dynamics with Hidden Markov Models. Proceedings of the Annual Meeting of the Cognitive Science Society, 2721-2726. https://escholarship.org/uc/item/06b952g5.

Moreno, R. (2010). Educational Psychology. New Jersey: John Wiley \& Sons.

Narvaez, D. (2006). Integrative Ethical Education. In M. Killen \& J. Smetana (Eds.), Handbook of Moral Development. New Jersey: Lawrence Erlbaum Associates.

Nucci, L. (2015). Moral Development and Education. In International Encyclopedia of the 
Social \& Behavioral Sciences, 2nd edition, Volume 15. Elsevier.

Piaget, J. (1977). Problem in Equlibration. Topics in Cognitive Development. https://doi.org/10.1007/978-1-4613-4175-8_1.

Plomp, T. (1997). Educational and Training System Design. New Nederlands: University of Twente Faculty of Educational Science and Technology.

Power, F. C., Higgins, A., Kohlberg, L., \& Reimer, J. (1989). Lawrence Kohlberg's Approach to Moral Education. New York: Columbia University Press.

Pritchard, A. (2009). Ways of Learning; Learning Theory and Learning Styles in the Classroom (2nd ed.). New York: Routledge.

Rest, J. R. (1992). Komponen-Komponen Utama Moralitas. In W. M. Kurtines \& J. L. Gerwitz (Eds.), Moralitas, Perilaku Moral, dan Perkembangan Moral. Jakarta: UI Press.

Snarey, J., \& Samuelson, P. (2014). Lawrence Kohlberg Revolusionary Ideas: Moral Education in the Cognitive-Developmental Tradition. In L. Nucci, D. Narvaez, \& T. Krettenauer (Eds.), Handbook or Moral and Character Education. New York: Routledge.

Sugiyono. (2016). Metode Penelitian \& Pengembangan: Research and Development untuk Bidang Pendidikan, Manajemen, Sosial, Teknik. Bandung: Alfabeta.

Susilawati, S. (2014). Pengaruh Penggunaan Metode Pembelajaran Moral dan Religiusitas terhadap Peningkatan Pertimbangan Moral. Malang: Universitas Negeri Malang.

Timmerman, P. (2014). Moral Contract Theory and Social Cognition. Switzerland: Springer International Publishing.

Yaqin, A. (2019a). Developing Moral Reasoning Theory Based on Islamic Education Perspective. Advances in Social Science, Education and Humanities Research. https://doi.org/10.2991/icei-19.2019.13.

Yaqin, A. (2019b). Membentuk Karakter melalui Pendidikan Afeksi. Yogyakarta: Media Akademi.

Yaqin, A. (2019c). Pengaruh Model Pembelajaran Akhlak Berbasis Kognitif Terhadap Moral Reasoning Siswa. IMTIYAS, 3(1). https://doi.org/10.46773/imtiyaz.v3i1.29.

Yaqin, A. (2020). Pendidikan Akhlak-Moral Berbasis Teori Kognitif. Depok: Rajawali Press. 